\title{
Cytotoxic and apoptotic evaluations of marine bacteria isolated from brine-seawater interface of the Red Sea
}

\author{
Sunil Sagar ${ }^{1 *}$, Luke Esau', Tyas Hikmawan², Andre Antunes², Karie Holtermann², Ulrich Stingl ${ }^{2}$, Vladimir B Bajic ${ }^{1}$ \\ and Mandeep Kaur ${ }^{1}$
}

\begin{abstract}
Background: High salinity and temperature combined with presence of heavy metals and low oxygen renders deep-sea anoxic brines of the Red Sea as one of the most extreme environments on Earth. The ability to adapt and survive in these extreme environments makes inhabiting bacteria interesting candidates for the search of novel bioactive molecules.

Methods: Total 20 i.e. lipophilic (chloroform) and hydrophilic (70\% ethanol) extracts of marine bacteria isolated from brine-seawater interface of the Red Sea were tested for cytotoxic and apoptotic activity against three human cancer cell lines, i.e. HeLa (cervical carcinoma), MCF-7 (Breast Adenocarcinoma) and DU145 (Prostate carcinoma).

Results: Among these, twelve extracts were found to be very active after 24 hours of treatment, which were further evaluated for their cytotoxic and apoptotic effects at $48 \mathrm{hr}$. The extracts from the isolates P1-37B and P3-37A (Halomonas) and P1-17B (Sulfitobacter) have been found to be the most potent against tested cancer cell lines.

Conclusion: Overall, bacterial isolates from the Red Sea displayed promising results and can be explored further to find novel drug-like molecules. The cell line specific activity of the extracts may be attributed to the presence of different polarity compounds or the cancer type i.e. biological differences in cell lines and different mechanisms of action of programmed cell death prevalent in different cancer cell lines.
\end{abstract}

Keywords: Marine bacteria, Deep sea brine pools, Extracts, Cytotoxicity, Apoptosis

\section{Background}

The marine environment is a rich source of unique bioactive molecules with unlimited chemical and functional diversity. Approximately 30,000 natural products have been isolated from marine organisms (http://dmnp.chemnetbase. com/intro/index.jsp) and many of the drug candidates are currently in clinical trials $[1,2]$. In the recent reports, both, deep sea water bodies and seafloors have been shown to be some of the most biodiverse and species-rich habitats on the planet $[3,4]$. The continuous search for new chemically diverse molecules and the development of new methods for culturing deep-sea microorganisms have placed the deep

\footnotetext{
* Correspondence: sunil.sagar@kaust.edu.sa

${ }^{1}$ King Abdullah University of Science and Technology (KAUST),

Computational Bioscience Research Center, Thuwal 23955-6900, Kingdom of Saudi Arabia

Full list of author information is available at the end of the article
}

sea environment as a new frontier in the drug discovery process. The general opinion is that the survival of deep sea organisms in the extreme conditions of pressure, absence of light, low levels of oxygen, high temperature and salt concentration may have affect their primary and secondary metabolite profiles $[5,6]$ which, in turn, can be suitable candidates for discovery of structurally unique molecules.

Siderophore Bisucaberin [7] was the first cytotoxic compound isolated from deep-sea marine bacteria Alteromonas haloplanktis, collected at $3000 \mathrm{~m}$ depth off the coast of Aomori Prefecture, Japan. Lately, Homann et al. reported the isolation of peptidic siderophores Loihichelins A-F [8] from the cultures of heterotrophic bacterium Halomonas LOB-5 collected from the southern rift zone of Loihi Seamount east of Hawaii. Novel cytotoxic phenazine derivatives [9] with unique ring system have been described from pacific sediment Bacillus sp. (5059 m depth). Several

\section{Ciomed Central}


other compounds with significant cytotoxic activity which were isolated from deep-sea Bacillus and Streptomyces sp. and actinomycete have been described by Danielle Skropeta in a recent review [10]. In our effort to exploit the biodiversity of these environments, several strains of marine bacteria were isolated from Kebrit Deep, Nereus Deep, Discovery Deep and Erba Deep of the Red Sea [11] and evaluated for their cytotoxic and apoptotic potential.

The Red Sea harbors approximately 25 deep-sea anoxic brine pools, which were formed by a process of redissolution of evaporitic deposits [12-14]. The deep-sea anoxic brines of the Red Sea are considered to be one of the most extreme environments on Earth, which are characterized by drastic changes in physicochemical conditions when compared to overlying seawater. This includes the increases in salinity (from $4 \%$ up to $26 \%$ salinity), temperature (up to $70^{\circ} \mathrm{C}$ ), concentrations of heavy metals, and decrease in oxygen $[15,16]$.

The present study describes the assessment of anticancer activity of marine microorganisms from the brine-seawater interface of the Red Sea. The cytotoxic activities of lipophilic, i.e. chloroform and hydrophilic, i.e. $70 \%$ ethanol extracts of marine bacteria isolated from deep sea brine pools of Red Sea, against HeLa (cervical carcinoma), MCF-7 (breast adenocarcinoma) and DU145 (prostate carcinoma) cell lines, were measured at $24 \mathrm{hr}$ time point. Some of the highly active extracts were further assessed for cytotoxicity and apoptotic activity at $48 \mathrm{hr}$.

\section{Methods}

\section{Field sampling}

Water samples from the brine-seawater interface were collected using a rosette sampler equipped with 101 Niskin bottles and a conductivity-temperature-depths (CTD) unit for monitoring salinity, temperature, transmission, and pressure. At each sampling site, $180 \mathrm{l}$ of samples were collected and pre-filtered through a $5.0 \mu \mathrm{m}$ SMWP membrane (diameter $290 \mathrm{~mm}$; Millipore, Ireland) to remove suspended particles, then filter-concentrated with Tangential Flow Filtration (TFF) system through Durapore $0.1 \mu \mathrm{m}$ PVDF filter (Pellicon 2 Cassette Filter, Screen type C, size $0.5 \mathrm{~m}^{2}$, Millipore Corporation, MA, USA). After filtration, one liter of each concentrated sample was stored in the dark at $4^{\circ} \mathrm{C}$ and was used as inoculum.

\section{Source of bacterial isolates}

Twelve strains of bacteria investigated in this study were isolated from brine-seawater interface of deep sea brines in the Red Sea. Brine-seawater samples for bacterial isolation were collected from four different deep brines named Discovery Deep (2050 m), Kebrit Deep (1549 m), Nereus Deep (2300 m), and Erba Deep (2300 m). Each of the deep sea brine has its unique physicochemical composition [11]. In the Discovery deep, brine-seawater boundaries are characterized by strong temperature and salinity gradients [14].

All of the bacterial strains isolated in this study were obtained by the streak plate method described elsewhere [17]. All of the strains grew in $10 \% \mathrm{NaCl}$ with the exception of one strain isolated from Discovery Deep. This strain was successfully isolated using $20 \% \mathrm{NaCl}$.

\section{PCR amplification}

PCR amplifications of the extracted DNA of the cultures were performed in a $25 \mu \mathrm{l}$ reaction having $12.5 \mu \mathrm{l}$ Promega PCR Master Mix (Promega, USA), $0.5 \mu \mathrm{l}$ (final concentration $0.5 \mu \mathrm{M}$ ) of primer 27bF (5'-AGAGTTTGATCMTGG CTCAG-3') and 1492uR (5'-TACCTTGTTACGACTT-3'). PCR reaction were carried out in Mastercycler (Eppendorf, Germany) under the following conditions: a pre-denaturation temperature of $95^{\circ} \mathrm{C}$ for $5 \mathrm{~min}$; 30 cycles of $95^{\circ} \mathrm{C}$ for $60 \mathrm{~s}$, $55^{\circ} \mathrm{C}$ for $60 \mathrm{~s}, 72^{\circ} \mathrm{C}$ for $30 \mathrm{~s}$; followed by final extension at $72^{\circ} \mathrm{C}$ for $5 \mathrm{~min}$. The yield and quality of the PCR products were examined on 1\% (wt/vol) agarose gel (SeaKem GTG, Lonza, USA) stained with SYBR Safe (Invitrogen, USA), then purified with Illustra Exostar 1-step (GE, Healthcare, UK) according to the manufacturer's protocol. The $16 \mathrm{~S}$ rRNA genes were sequenced with an ABI 3730xl capillary DNA sequencer (PE Applied Biosystems), at Core Lab. KAUST, Saudi Arabia.

\section{Bacterial biomass}

Strains of halophilic bacteria were isolated into pure culture by streaking the samples onto three different solid media types, marine agar 2216 (Difco), plate count agar (Teknova), and R2A agar (Oxoid). These media were supplemented with either $10 \%$ or $20 \% \mathrm{NaCl}$ to adjust salinity. All plates were incubated at $30^{\circ} \mathrm{C}$ and inspected daily for two weeks. Colonies with different morphologies were picked and pure cultures of these colonies were obtained after three transfers. Taxonomic identifications were based on $16 \mathrm{~S}$ rRNA gene sequencing. DNA extraction of the pure cultures, $16 \mathrm{~S}$ rRNA gene amplification, and sequencing were performed according to [18]. A BLASTN search was used to identify strains to their closest relatives in GenBank. To prepare extracts, bacteria were grown in $1 \mathrm{~L}$ of Marine Broth (Difco) supplemented with $\mathrm{NaCl}$. Cultures were incubated at $30^{\circ} \mathrm{C}$ in a shaking incubator and harvested after two weeks by centrifugation. Cell pellets were frozen at $-80^{\circ} \mathrm{C}$ until used for extract preparation.

\section{Extract preparation}

Lipophilic, i.e. chloroform and hydrophilic, i.e. 70\% ethanol, extracts of 12 strains of marine bacteria were prepared at a concentration of $100 \mathrm{mg} \mathrm{mL}^{-1}$ (speedvac dried material $/ \mathrm{mL}$ of solvent). Solutions were sonicated with ultra-sound probe (Biologics Inc., Model $150 \mathrm{~V} / \mathrm{T}$ ) for $3 \times 2$ minutes on ice. The solutions were centrifuged at $10000 \mathrm{~g}$ for 
15 minutes; the supernatants were recovered and stored at $-20^{\circ} \mathrm{C}$

\section{Cell culture}

MCF-7 (Breast Adenocarcinoma), DU145 (Prostate carcinoma) and HeLa (Cervical carcinoma) were obtained from the American Type Cell Culture Collection (ATCC, Manassas, VA). All cell lines were cultured in DMEM (Dulbecco's Modified Eagle's Medium), supplemented with $10 \%$ FCS (Fetal calf serum), penicillin $(100 \mathrm{U} / \mathrm{ml})$ and streptomycin $(100 \mu \mathrm{g} / \mathrm{ml})$ at $5 \% \mathrm{CO}_{2}$ in a $37^{\circ} \mathrm{C}$ incubator.

\section{MTT assay}

The cytotoxicity of marine bacterial extracts was estimated by MTT (3-(4, 5-Dimethylthiazol-2-yl)-2, 5diphenyltetrazolium bromide) assay. Cells were seeded at a density of $2.5 \times 10^{3}$ cells per well in a 384-well culture plates and treated with $1 \mathrm{mg} / \mathrm{mL}$ marine bacterial extract for 24 and $48 \mathrm{hr}$ (hours). Cells were treated with $5 \mathrm{mM}$ $\mathrm{H}_{2} \mathrm{O}_{2}$ as a positive control. Following incubation with extracts, $5 \mu \mathrm{l}$ of sterile MTT $(5 \mathrm{mg} / \mathrm{mL}$ ) dissolved in PBS was added to each well and incubated with cells for $4 \mathrm{hr}$ followed by the addition of $30 \mu \mathrm{l}$ of solubilisation solution $(10 \% \mathrm{SDS}, 10 \mathrm{mM} \mathrm{HCl})$ which was incubated with cells for $16 \mathrm{hr}$ at $37^{\circ} \mathrm{C}$. The OD (optical density) of each well was measured at $595 \mathrm{~nm}$ using a microtiter plate reader (BMG Labtech PHERAstar FS, Germany) and results were analyzed using Microsoft Office Excel ${ }^{\circledR}$.

\section{APOPercentage assay}

The cells were seeded in 96 well plates at a density of $5 \times 10^{3}$ cells per well in duplicate in $90 \mu \mathrm{l}$ of media. After $24 \mathrm{hr}$, cells were treated with marine bacterial extracts diluted in complete DMEM to a final concentration of $1 \mathrm{mg} / \mathrm{mL}$ and incubated at $37^{\circ} \mathrm{C}$ for $48 \mathrm{hr}$. Cells were treated with $2.5 \mathrm{mM} \mathrm{H}_{2} \mathrm{O}_{2}$ for 30 minutes as a positive control. The cells were stained with APOPercentage dye as per manufacturer's instructions (Biocolor, UK). Duplicates were pooled, the OD was measured at $550 \mathrm{~nm}$ absorbance using a microtiter plate reader (BMG Labtech PHERAstar FS, Germany) and percentage staining was calculated.

\section{Statistical analysis}

Student's $t$-test was used to compare the samples (treated vs. Untreated) and were noted to be statistically significantly different where $\mathrm{p}<0.05$. All statistics including mean and SD calculations were performed using Microsoft Office Excel $^{\odot}$.

\section{Results}

\section{Microbial isolates}

Twelve strains of marine bacteria were isolated from the Kebrit Deep, Nereus Deep, Discovery Deep and Erba Deep of the Red Sea (Table 1). The isolation of bacteria and their culturing were done by Red Sea Research Center at King Abdullah University of Science and Technology. Total 20 extracts i.e. lipophilic (chloroform) and hydrophilic ( $70 \%$ ethanol) have been investigated for their anticancer potential against above mentioned three human cancer cell lines.

\section{Cytotoxic activities of bacterial extracts}

Cytotoxic activities for the extracts were assessed by MTT assay. The growth inhibitions were measured after treating the cell lines with microbial extracts for $24 \mathrm{hr}$ (Figures 1, 2 and 3). Out of total 20 bacterial extracts, 13 extracts i.e. $2 \mathrm{C}, 5 \mathrm{C}, 7 \mathrm{C}, 8 \mathrm{C}, 11 \mathrm{C}, 1 \mathrm{E}, 4 \mathrm{E}, 5 \mathrm{E}, 6 \mathrm{E}, 7 \mathrm{E}$, 9E, 10E and 11E displayed maximum growth inhibitory effects on different cancer cell lines. The specific activity of different extracts for particular cell lines may be attributed to the presence of different polarity compounds. Extracts 2C, 5C, 11C, 4E, 5E, 7E and 11E (Figure 1) showed $40-60 \%$ of growth inhibition in MCF-7 cells.

Table 1 Taxonomic identification, location of collection and source of origin for 12 microbial strains

\begin{tabular}{|c|c|c|c|c|c|c|c|}
\hline Chloroform extract & Ethanol extract & Isolate & Source & Closest relative & Similarity & GenBank access no. & Ref \\
\hline- & $1 \mathrm{E}$ & P1-17B & Kebrit interface & Sulfitobacter pontiacus & $99 \%$ & NR_026418.1 & [19] \\
\hline $2 C$ & - & P1-37B & Nereus interface & Halomonas meridiana & $100 \%$ & AF212217.2 & [20] \\
\hline $3 C$ & $3 \mathrm{E}$ & P3-82 & Erba interface & Halomonas meridiana & $100 \%$ & AF212217.2 & [20] \\
\hline $4 C$ & $4 \mathrm{E}$ & P5-16A & Kebrit interface & Halomonas axialensis & $100 \%$ & NR_027219.1 & [21] \\
\hline $5 C$ & $5 E$ & P5-16B & Kebrit interface & Halomonas axialensis & $100 \%$ & NR_027219.1 & [21] \\
\hline $6 C$ & $6 \mathrm{E}$ & P5-37A & Nereus interface & Halomonas meridiana & $99 \%$ & AF212217.2 & [20] \\
\hline $7 C$ & $7 \mathrm{E}$ & P5-82 & Erba interface & Idiomarina baltica & $99 \%$ & AJ440215.1 & [22] \\
\hline $8 C$ & - & P1-37A & Nereus interface & Marinobacter bryozoorum & $98 \%$ & NR_027192.1 & {$[2$} \\
\hline $9 C$ & $9 \mathrm{E}$ & P1-82 & Erba interface & Halomonas meridiana & $100 \%$ & NR_042066.1 & {$[24$} \\
\hline $10 C$ & $10 \mathrm{E}$ & P1-16B & Kebrit interface & Vibrio sinaloensis & $98 \%$ & NR_043858.1 & {$[2$} \\
\hline $11 C$ & $11 \mathrm{E}$ & P3-37A & Nereus interface & Halomonas aquamarina & $100 \%$ & HQ188659.1 & [2 \\
\hline $12 \mathrm{C}$ & - & P6-86 & Discovery interface & Chromohaloba-cter salexigens & $99 \%$ & EU868854.1 & {$[27$} \\
\hline
\end{tabular}




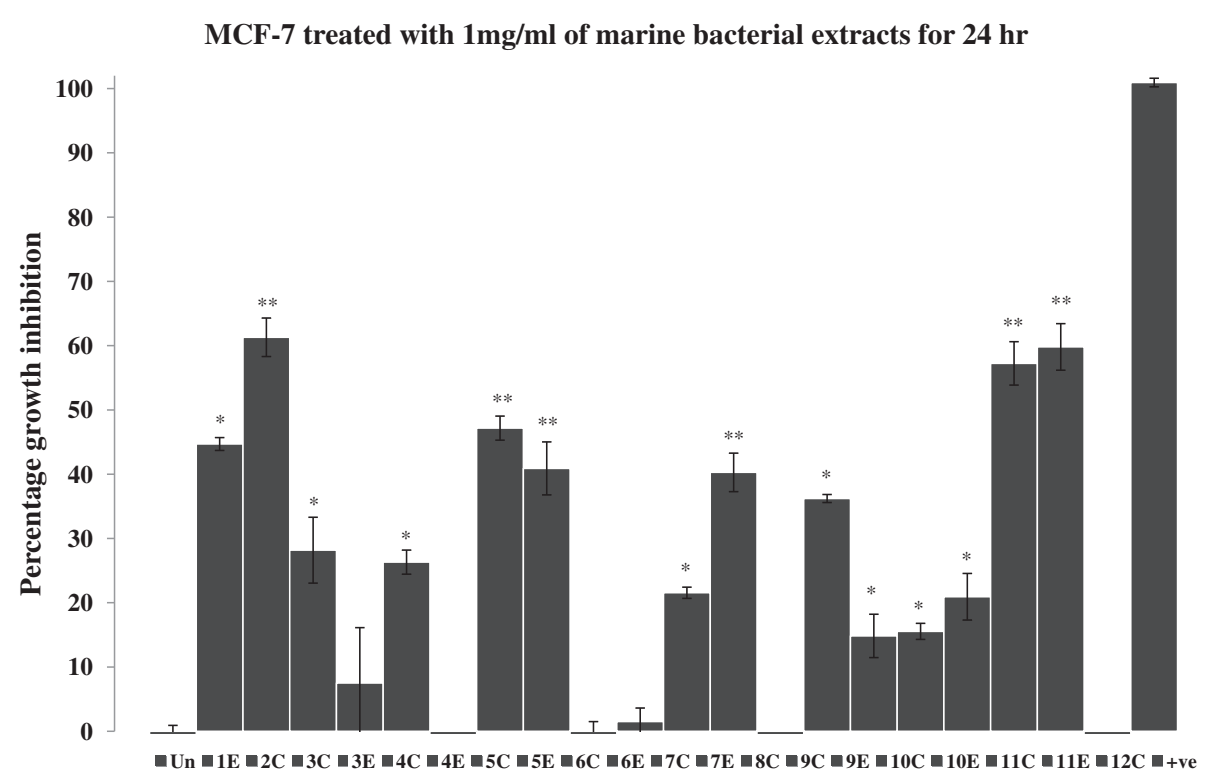

Figure 1 Percent growth inhibition of MCF-7 cells after treatment with $1 \mathrm{mg} / \mathrm{mL}$ marine bacterial extracts for $24 \mathrm{hr}$. Data were normalized to DMSO treatment controls, and error bars represent the standard deviation for triplicate experiments. Values marked as asterisk $\left({ }^{*} \mathrm{p}<0.05\right.$ and $\left.{ }^{* *} \mathrm{p}<0.01\right)$ are significantly different from untreated control $(U n) .+$ ve represents positive control $\left(\mathrm{H}_{2} \mathrm{O}_{2}\right)$.

Bacterial extracts 5C, 1E, 5E and 7E (Figure 2) demonstrated $50-70 \%$ growth inhibition against HeLa cells. Extracts $1 \mathrm{E}$ and $5 \mathrm{E}$ were found to be highly active against HeLa with growth inhibition of $70 \%$ and $60 \%$ respectively. Similarly, extracts 1E, 5E, 7E and 9E inhibited the growth of DU145 cells by $40 \%$ or more after $24 \mathrm{hr}$ of treatment (Figure 3 ). Extract 1E was the most active fraction against DU145 with about $70 \%$ growth inhibition. The comparison of data (Figures 1, 2 and 3) revealed that extract 11E is most active in MCF-7 but comparatively has low cytotoxic activity in HeLa and DU145 cells. Also, extracts 4E and $6 \mathrm{E}$ are only active against HeLa cells $(20 \%$ and $30 \%$ growth inhibition respectively) and do not affect MCF-7 and DU145 cells. Overall, the results showed

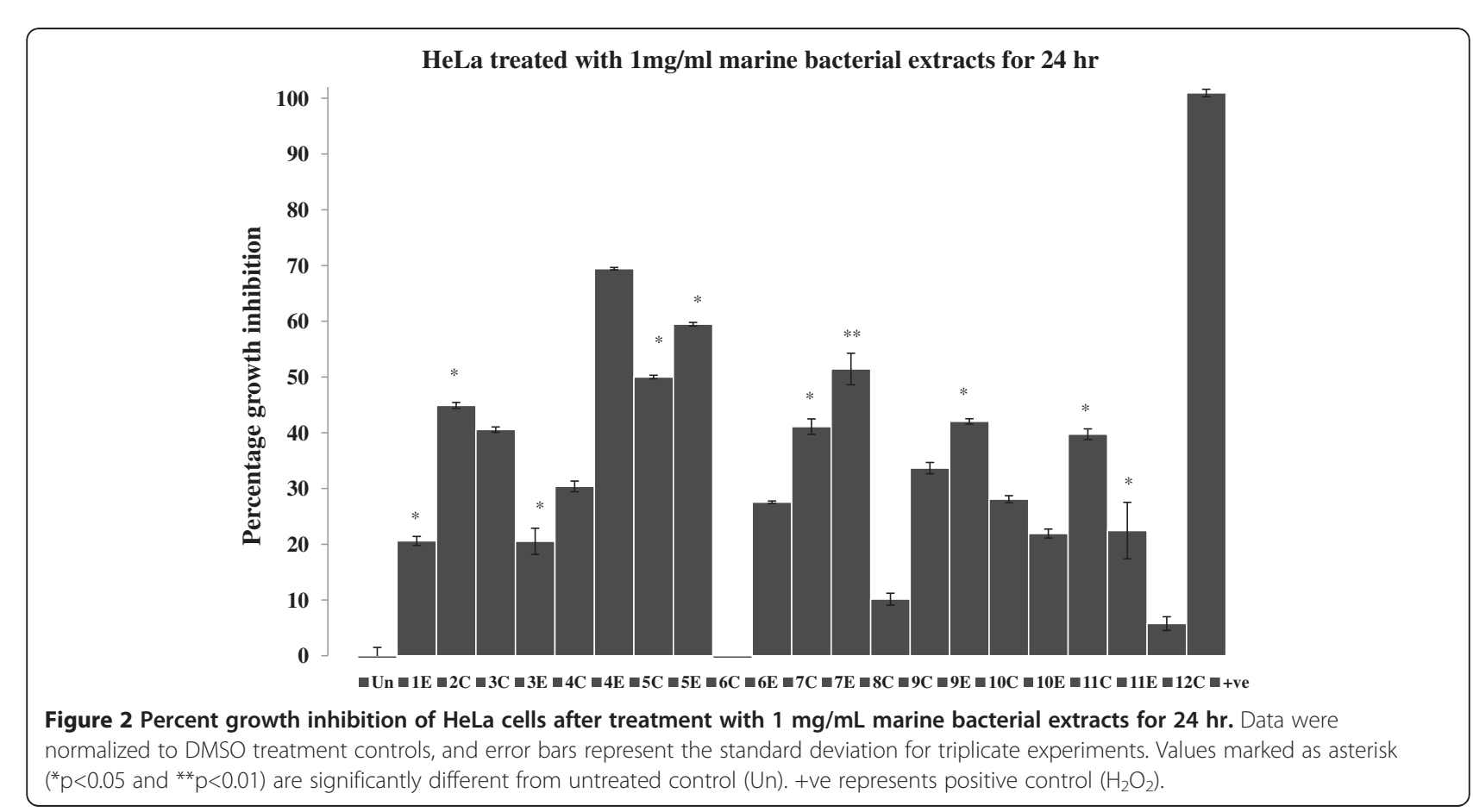




\section{DU145 treated with $1 \mathrm{mg} / \mathrm{ml}$ of marine bacterial extracts for $24 \mathrm{hr}$}

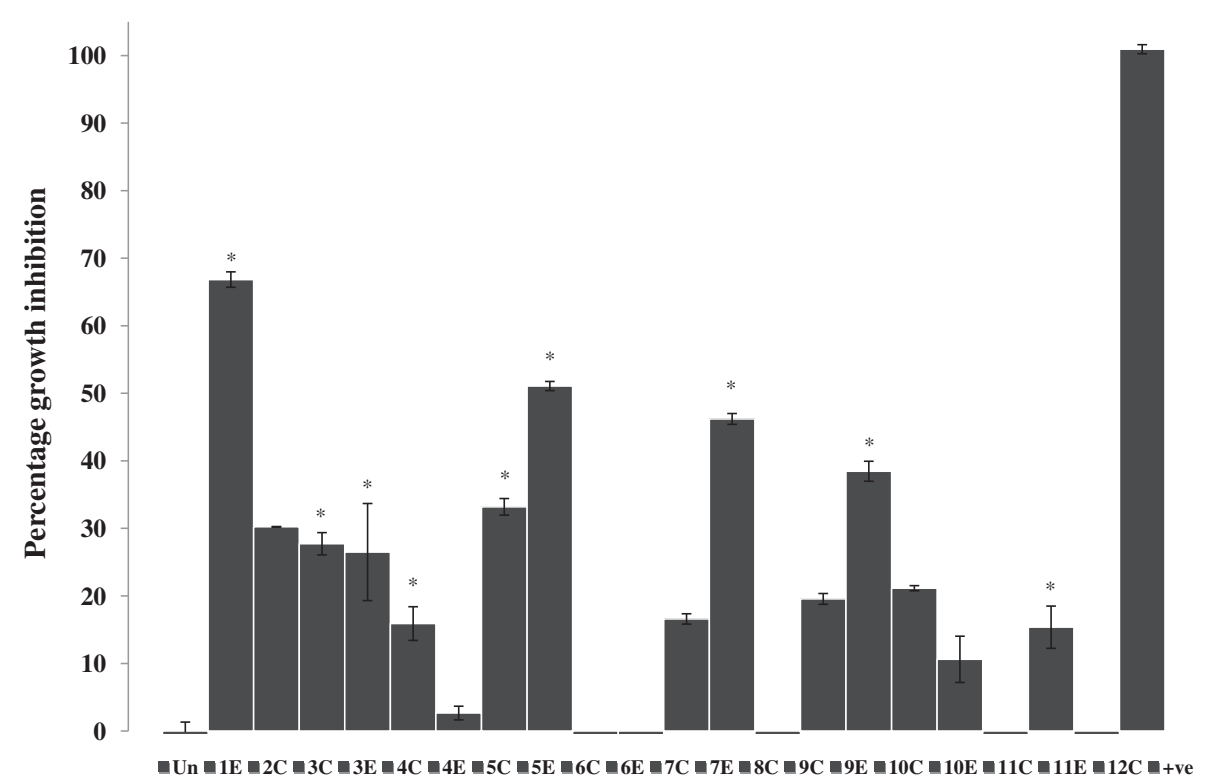

Figure 3 Percent growth inhibition of DU145 cells after treatment with $1 \mathrm{mg} / \mathrm{mL}$ marine bacterial extracts for $24 \mathrm{hr}$. Data were normalized to DMSO treatment controls, and error bars represent the standard deviation for triplicate experiments. Values marked as asterisk $\left({ }^{*} p<0.05\right.$ and $\left.{ }^{* *} p<0.01\right)$ are significantly different from untreated control $(U n) .+$ ve represents positive control $\left(\mathrm{H}_{2} \mathrm{O}_{2}\right)$.

that marine bacterial extracts have cell line specific cytotoxic activity.

To observe the long term effects of the bacterial extracts on the growth of cancer cell lines, the lead extracts $(2 \mathrm{C}$, 5C, 7C, 8C, 11C, 1E, 4E, 5E, 6E, 7E, 10E and 11E) were further evaluated for cytotoxicity at $48 \mathrm{hr}$ time point. These extracts were selected based on their activities and availability. Cell growth inhibition induced by some of the extracts was increased with time (Table 2) while for others the growth inhibition decreases slightly which may indicate the recovery of the cells, especially in the case of MCF-7 cells.

\section{Apoptotic evaluations}

To further confirm that the mode of cell death is via apoptosis, the lead marine bacterial extracts $(2 \mathrm{C}, 5 \mathrm{C}, \mathbf{1 1 C}$, 1E, 4E, 5E, 7E, 10E and 11E) were evaluated by APOPercentage assay. The results for this assay showed that most of the lead extracts induced apoptosis in HeLa cells (Figure 4), while in DU145 and MCF-7 cells, no significant apoptotic effect was observed at $48 \mathrm{hr}$ time point, however, the bacterial extract $2 \mathrm{C}$ showed high apoptotic activity in MCF-7 cells (Figure 4).

\section{Discussion}

The results showed that most of the microbial extracts from the brine pools of the Red Sea have displayed significant cytotoxic and apoptotic activity. Cytotoxicity which was measured by MTT assay (3-[4, 5-dimethylthiazol-2-yl]-2, 5 -diphenyltetrazolium bromide), targets the activity of succinate dehydrogenase in mitochondria which in turn reduces the tetrazolium salt into formazan crystals [28]. The intensity of the color of formazan dye correlates to the number of viable cells. The isolates P1-37B (2C) and P3-37A (11C and 11E) which has $100 \%$ sequence similarity to

Table 2 The comparison of percentage growth inhibition of HeLa, MCF-7 and DU145 cells after treatment with $1 \mathrm{mg} / \mathrm{mL}$ marine bacterial extracts in triplicate for 24 and $48 \mathrm{hr}$

\begin{tabular}{|c|c|c|c|c|c|c|}
\hline \multirow{2}{*}{$\begin{array}{l}\text { Marine } \\
\text { bacterial } \\
\text { extract }\end{array}$} & \multicolumn{2}{|c|}{ HeLa } & \multicolumn{2}{|c|}{ MCF-7 } & \multicolumn{2}{|c|}{ DU145 } \\
\hline & $24 \mathrm{hr}$ & $48 \mathrm{hr}$ & $24 \mathrm{hr}$ & $48 \mathrm{hr}$ & $24 \mathrm{hr}$ & $48 \mathrm{hr}$ \\
\hline $2 C$ & 44.906 & 58.003 & 61.307 & 78.608 & 30.233 & 86.682 \\
\hline $5 C$ & 50.000 & 41.931 & 47.173 & 7.654 & 33.194 & 50.260 \\
\hline $7 C$ & 41.094 & 38.250 & 21.555 & -17.160 & 16.597 & 15.263 \\
\hline $8 C$ & 10.151 & 23.494 & -3.180 & -25.303 & -9.779 & 16.262 \\
\hline $11 C$ & 39.736 & 50.176 & 57.244 & 36.271 & -8.074 & 54.699 \\
\hline $1 \mathrm{E}$ & 69.434 & 61.787 & 44.700 & 13.560 & 66.836 & 59.324 \\
\hline $4 \mathrm{E}$ & 20.604 & 34.164 & -3.710 & -10.350 & 2.661 & 37.471 \\
\hline $5 E$ & 59.472 & 41.556 & 40.901 & 24.234 & 51.077 & 47.287 \\
\hline $6 \mathrm{E}$ & 27.547 & 15.256 & 1.502 & -23.946 & -7.775 & 21.345 \\
\hline $7 \mathrm{E}$ & 51.434 & 42.027 & 40.283 & 20.021 & 46.202 & 47.725 \\
\hline $10 \mathrm{E}$ & 21.925 & 9.215 & 20.936 & 8.992 & 10.616 & 15.956 \\
\hline $11 E$ & 22.453 & 29.769 & 59.806 & 16.475 & 15.371 & 45.672 \\
\hline
\end{tabular}

Data were normalized to DMSO treatment control. 




Figure 4 Percent apoptosis in HeLa, DU145 and MCF-7 cells after treatment with $1 \mathrm{mg} / \mathrm{mL}$ marine bacterial extracts. The treatment of extracts was done for $48 \mathrm{hr}$ in duplicates. Data were normalized to untreated controls.

Halomonas (Table 1) showed about $60 \%$ growth inhibition (Figure 1) in MCF-7 cell line. Not much work has been done on the anticancer activities of Halomonas sp. and very few studies have been reported so far. Marine bacterial strain GWS-BW-H8hM was reported to inhibit growth of HM02 (gastric adenocarcinoma), HepG2 (hepatocellular carcinoma) and MCF7 cell lines and induce apoptosis via cell cycle arrest [29]. Highly heterogeneous polymers i.e. exopolysaccharides (EPSs) and sulphated EPSs isolated from $H$. stenophila sp. inhabiting hypersaline environment have also been reported for their pro-apoptotic effects on T-leukemia cells [30]. A range of amphiphilic siderophores, loihichelins A-F, consisting of an octapeptide comprised of D-threo- $\beta$ hydroxyaspartic acid, D-serine, L-glutamine, L-serine, $\mathrm{L}-\mathrm{N}(\delta)$-acetyl- $\mathrm{N}(\delta)$-hydroxyornithine, dehydroamino-2butyric acid, $\mathrm{D}$-serine, and cyclic $\mathrm{N}(\delta)$-hydroxy-D-ornithine, appended by one of a series of fatty acids ranging from decanoic acid to tetradecanoic acid have been isolated from cultures of the marine bacterium Halomonas sp. LOB-5 [8]. The isolation of cytotoxic hydroxyphenylpyrroledicarboxylic acids i.e. 3-(4_-hydroxyphenyl)-4-phenylpyrrole2,5-dicarboxylic acid (HPPD-1), 3,4-di-(4_-hydroxy-phenyl) pyrrole-2,5- dicarboxylic acid (HPPD-2) and the literature-known indole derivatives 3-(hydroxyacetyl)-indole, indole-3- carboxylic acid, indole-3-carboxaldehyde, and indole-3-acetic acid have also been reported from a marine Halomonas sp. [31]. Both HPPD-1 and HPPD-2 have shown potent antitumor- promoting activities. Two most active extracts were obtained from the isolates P117B (1E) and P5-16B (5E), which inhibited the cell growth by $50-70 \%$ (Figures 2 and 3) in HeLa and DU145 cells and showed sequence similarity of $100 \%$ to Sulfitobacter and Halomonas respectively (Table 1 ). The cytotoxic activity observed in isolates P1-37B and P3-37A (Halomonas) could be due to the above mentioned cytotoxic compounds from Halomonas sp.. No published records were found in PubMed regarding the cytotoxic activities and isolation of bioactive molecules from Sulfitobacter. The most prominent effect was found for extract 1E (Isolate P1-17B- Sulfitobacter) for HeLa and DU145 cell lines which makes it a suitable candidate for future isolation of bioactive molecules. Cytotoxic effects for the most active extracts were also observed at $48 \mathrm{hr}$ time point and activity for some of these extracts were found to be lower than that at $24 \mathrm{hr}$ (Table 2, see non-bold numbers). It may be due to the recovery of the cells from the effects of these extracts. In general the hydrophilic extracts were found to be more active than lipophilic extracts, which may indicate the presence of significant amount of cytotoxic compounds in the polar fractions as compared to the non-polar fractions.

To further confirm the cell death via apoptotic mode, APOPercentage assay was performed on the most active extracts. Apoptosis is a form of a programmed cell death where cell undergo specific hallmark changes during progression towards death [32]. It has been established that apoptosis plays a key role in death of cancer as well as normal cells [33]. The APOPercentage assay (http://www.biocolor.co.uk/) captures apoptotic cells representing a hallmark change on the surface of plasma membranes i.e. phosphatidylserine (PS) externalization. PS is found in the inner leaflet and is exposed to outer leaflet during apoptosis and this externalized PS acts as a recognition tag for multiple processes including macrophages and phagocytosis $[34,35]$. The maximum apoptotic activity was displayed by isolate P1-37B (2C) in both HeLa as well as MCF-7 cells (Figure 4). Similar 
studies targeting bacterial extracts from other marine habitats have been published previously, mainly targeting cyanobacteria [36] and bacteria associated with other marine organisms such as seaweeds and invertebrates [37] and sponges $[38,39]$.

The cell line specific activity of the extracts may be attributed to the different polarity compounds. Previous studies on different cancer cell lines have shown that the variable response of cell lines towards apoptosis inducers may also be attributed to the cancer type i.e. biological differences in cell lines and different mechanisms of action of programmed cell death prevalent in different cancer cell lines [40]. Even the timeline of progression through apoptosis process can vary among cell lines [41,42].

\section{Conclusions}

In conclusion, present work showed that extracts of most of the marine bacterial strains collected from interface of brine pools and sea water of the Red Sea have displayed significant growth inhibitory and apoptotic effect on the various cancer cell lines. The extracts from the isolates P1-37B and P3-37A (Halomonas) and P1-17B (Sulfitobacter) have been found to be the most potent against tested cancer cell lines and could be the lead candidates for the future work of isolation and structure elucidation of bioactive molecules.

\section{Abbreviations}

CTD: Conductivity-temperature-depths; TFF: Tangential Flow Filtration; DMEM: Dulbecco's Modified Eagle's Medium; FCS: Fetal calf serum; OD: Optical density; MTT: 3-(4, 5-Dimethylthiazol-2-yl)-2, 5diphenyltetrazolium bromide; PS: Phosphatidylserine; HeLa: Cervical carcinoma; MCF-7: Breast Adenocarcinoma; DU145: Prostate carcinoma.

\section{Competing interests}

The authors declare that they have no competing financial interests.

\section{Authors' contribution}

SS and MK planned the study, wrote manuscript and performed experiments along with LE. TH isolated the strains and provides taxonomic classification of the bacterial strains. AA was responsible for the sample collection. $\mathrm{KH}$ was responsible for growth of the strains in large batches. US was responsible for the planning of the expedition and the cultivation experiments, provided general coordination of the study and helped in manuscript writing. VBB provided general coordination of the study and helped in manuscript writing. All authors read and approved the final manuscript.

\section{Acknowledgments}

We acknowledge the crew of the RV Aegaeo and the KAUST core facility for marine research for help during the expedition. This study was funded partly by the SEDCO Research Excellence Award to US and VBB.

\section{Author details}

${ }^{1}$ King Abdullah University of Science and Technology (KAUST), Computational Bioscience Research Center, Thuwal 23955-6900, Kingdom of Saudi Arabia. ${ }^{2}$ King Abdullah University of Science and Technology (KAUST), Red Sea Research Center, Thuwal 23955-6900, Kingdom of Saudi Arabia.

Received: 2 October 2012 Accepted: 1 February 2013

Published: 6 February 2013

\section{References}

1. Roberts JM, Wheeler AJ, Freiwald A: Reefs of the deep: the biology and geology of cold-water coral ecosystems. Science 2006, 312:543-547.

2. Newman DJ, Cragg GM: Marine natural products and related compounds in clinical and advanced preclinical trials. J Nat Prod 2004, 67:1216-1238.

3. Brandt A, Gooday AJ, Brandao SN, Brix S, Brokeland W, Cedhagen T, Choudhury M, Cornelius N, Danis B, De Mesel I, et al: First insights into the biodiversity and biogeography of the Southern Ocean deep sea. Nature 2007, 447:307-311.

4. Snelgrove PVR, Smith CR: A riot of species in an environmental calm: The paradox of the species-rich deep-sea floor. In Oceanography and Marine Biology, Vol 40. Volume 40. Edited by Gibson RN, Barnes M, Atkinson RJA. London: Taylor \& Francis Ltd; 2002:311-342. Oceanography and Marine Biology].

5. Wright PC, Westacott RE, Burja AM: Piezotolerance as a metabolic engineering tool for the biosynthesis of natural products. Biomol Eng 2003, 20:325-331.

6. Bull AT, Ward AC, Goodfellow M: Search and discovery strategies for biotechnology: the paradigm shift. Microbio/ Mol Biol Rev 2000, 64:573-606.

7. Kameyama T, Takahashi A, Kurasawa S, Ishizuka M, Okami Y, Takeuchi T, Umezawa $\mathrm{H}$ : Bisucaberin, a new siderophore, sensitizing tumor cells to macrophage-mediated cytolysis. I. Taxonomy of the producing organism, isolation and biological properties. J Antibiot 1987, 40:1664.

8. Homann W, Sandy M, Tincu JA, Templeton AS, Tebo BM, Butler A: Loihichelins A- F, a Suite of Amphiphilic Siderophores Produced by the Marine Bacterium Halomonas LOB-5. J Nat Prod 2009, 72:884-888.

9. Li D, Wang F, Xiao X, Zeng X, Gu QQ, Zhu W: a new cytotoxic phenazine derivative from a deep sea bacterium Bacillus sp. Arch Pharm Res 2007, 30:552-555.

10. Skropeta D: Deep-sea natural products. Nat Prod Rep 2008, 25:1131-1166

11. Antunes A, Ngugi DK, Stingl U: Microbiology of the Red Sea (and other) deep--sea anoxic brine lakes. Environ Microbiol Rep 2011, 3:416-433.

12. Bonatti E: Punctiform initiation of seafloor spreading in the Red Sea during transition from a continental to an oceanic rift. Nature 1985, 316:33-37.

13. Craig H: Isotopic composition and origin of the Red Sea and Salton Sea geothermal brines. Science 1966, 154:1544-1548.

14. Hartmann M, Scholten J, Stoffers P, Wehner F: Hydrographic structure of brine-filled deeps in the Red Sea-new results from the Shaban, Kebrit, Atlantis II, and Discovery Deep. Mar Geol 1998, 144:311-330.

15. Anschutz $P$, Blanc G: The development of layering, fluxes through double-diffusive interfaces, and location of hydrothermal sources. J Geophys Res 1998, 103:27,809-827,819.

16. Schmidt M, Botz R, Faber E, Schmitt M, Poggenburg J, Garbe-Schönberg D, Stoffers $P$ : High-resolution methane profiles across anoxic brine-seawater boundaries in the Atlantis-II, Discovery, and Kebrit deeps (Red Sea). Chem Geol 2003, 200:359-375.

17. Beech FW, Davenport RR: Isolation, purification, and maintenance of yeasts. In Methods in microbiology. Vol. 4. Edited by Booth C. London: Academic Press; 1971:169.

18. Dieffenbach CW, Dveksler GS: PCR primer: a laboratory manual. New York: Cold Spring Harbor Laboratory Pr; 2003.

19. Sorokin DY: Sulfitobacter pontiacus gen. nov., sp. nov. - a new heterotrophic bacterium from the Black Sea, specialized on sulfite oxidation. Microbiology 1995, 64:295-305.

20. Kaye JZ, Baross JA: High incidence of halotolerant bacteria in Pacific hydrothermal-vent and pelagic environments. FEMS Microbiol Ecol 2000, 32:249-260.

21. Kaye JZ, Marquez MC, Ventosa A, Baross JA: Halomonas neptunia sp. nov. Halomonas sulfidaeris sp. nov. Halomonas axialensis sp. nov. and Halomonas hydrothermalis sp. nov.: halophilic bacteria isolated from deepsea hydrothermal-vent environments. Int J Syst Evol Micr 2004, 54:499-511.

22. Brettar I, Christen R, Hofle MG: Idiomarina baltica sp. nov. a marine bacterium with a high optimum growth temperature isolated from surface water of the central Baltic Sea. Int J Syst Evol Micr 2003, 53:407-413.

23. Romanenko LA, Schumann P, Rohde M, Zhukova NV, Mikhailov W Stackebrandt E: Marinobacter bryozoorum sp. nov. and Marinobacter sediminum sp. nov. novel bacteria from the marine environment. Int J Syst Evol Micr 2005, 55:143-148.

24. Arahal DR, Ludwig W, Schleifer KH, Ventosa A: Phylogeny of the family Halomonadaceae based on $23 \mathrm{~S}$ and 165 rDNA sequence analyses. Int J Syst Evol Micr 2002, 52:241-249. 
25. Gomez-Gil B, Fajer-Avila E, Pascual J, Macian MC, Pujalte MJ, Garay E, Roque A: Vibrio sinaloensis sp. nov. isolated from the spotted rose snapper, Lutjanus guttatus Steindachner, 1869. Int I Syst Evol Micr 2008, 58:1621-1624.

26. Cho BC, Hwang CY: Prokaryotic abundance and 165 rRNA gene sequences detected in marine aerosols on the East Sea (Korea). FEMS Microbiol Ecol 2011, 76:327-341.

27. Tang J, Zheng A-p, Bromfield E, Zhu J, Li S-c, Wang S-q, Deng Q-m, Li P: $16 \mathrm{~S}$ rRNA gene sequence analysis of halophilic and halotolerant bacteria isolated from a hypersaline pond in Sichuan, China. Ann Microbiol 2011, 61:375-381.

28. Wang $\mathrm{HZ}$, Chang $\mathrm{CH}$, Lin CP, Tsai MC: Using MTT viability assay to test the cytotoxicity of antibiotics and steroid to cultured porcine corneal endothelial cells. J Ocul Pharmacol Ther 1996, 12:35-43.

29. Bitzer J, Grosse T, Wang L, Lang S, Beil W, Zeeck A: New aminophenoxazinones from a marine Halomonas sp. fermentation structure elucidation, and biological activity. J Antibiot (Tokyo) 2006, 59:86-92.

30. Ruiz-Ruiz C, Srivastava GK, Carranza D, Mata JA, Llamas I, Santamaria M, Quesada E, Molina IJ: An exopolysaccharide produced by the novel halophilic bacterium Halomonas stenophila strain B100 selectively induces apoptosis in human T leukaemia cells. Appl Microbiol Biotechnol 2011, 89:345-355

31. Wang L, Grosse T, Stevens H, Brinkhoff T, Simon M, Liang L, Bitzer J, Bach G, Zeeck A, Tokuda H, Lang S: Bioactive hydroxyphenylpyrrole-dicarboxylic acids from a new marine Halomonas sp. Production and structure elucidation. Appl Microbiol Biotechnol 2006, 72:816-822.

32. Schwartz LM, Osborne BA: Programmed cell death, apoptosis and killer genes. Immunol Today 1993, 14:582-590.

33. Lowe SW, Lin AW: Apoptosis in cancer. Carcinogenesis 2000, 21:485-495.

34. Fadok VA, Laszlo DJ, Noble PW, Weinstein L, Riches DW, Henson PM: Particle digestibility is required for induction of the phosphatidylserine recognition mechanism used by murine macrophages to phagocytose apoptotic cells. J Immunol 1993, 151:4274-4285.

35. Fadok VA, Voelker DR, Campbell PA, Cohen JJ, Bratton DL, Henson PM: Exposure of phosphatidylserine on the surface of apoptotic lymphocytes triggers specific recognition and removal by macrophages. J Immunol 1992, 148:2207-2216.

36. Martins RF, Ramos MF, Herfindal L, Sousa JA, Skaerven K, Vasconcelos VM: Antimicrobial and cytotoxic assessment of marine cyanobacteria Synechocystis and Synechococcus. Mar Drugs 2008, 6:1-11.

37. Lin J, Yan XJ, Zheng L, Ma HH, Chen HM: Cytotoxicity and apoptosis induction of some selected marine bacteria metabolites. J Appl Microbiol 2005, 99:1373-1382.

38. Schupp PJ, Kohlert-Schupp C, Whitefield S, Engemann A, Rohde S, Hemscheidt T, Pezzuto JM, Kondratyuk TP, Park EJ, Marler L, et al: Cancer chemopreventive and anticancer evaluation of extracts and fractions from marine macro- and microorganisms collected from Twilight Zone waters around Guam. Nat Prod Commun 2009, 4:1717-1728.

39. Thakur AN, Thakur NL, Indap MM, Pandit RA, Datar W, Muller WE: Antiangiogenic, antimicrobial, and cytotoxic potential of spongeassociated bacteria. Mar Biotechnol (NY) 2005, 7:245-252.

40. Studzinski GP: Cell growth and apoptosis: a practical approach. Oxford: IRL Press at the Oxford University Press; 1995.

41. Härtel S, Zorn-Kruppa M, Tykhonova S, Alajuuma P, Engelke M, Diehl HA: Staurosporine--induced apoptosis in human cornea epithelial cells in vitro. Cytometry A 2003, 55:15-23.

42. Jessel R, Haertel S, Socaciu C, Tykhonova S, Diehl HA: Kinetics of apoptotic markers in exogeneously induced apoptosis of EL4 cells. J Cell Mol Med 2002, 6:82-92

doi:10.1186/1472-6882-13-29

Cite this article as: Sagar et al: Cytotoxic and apoptotic evaluations of marine bacteria isolated from brine-seawater interface of the Red Sea. BMC Complementary and Alternative Medicine 2013 13:29.

\section{Submit your next manuscript to BioMed Central and take full advantage of:}

- Convenient online submission

- Thorough peer review

- No space constraints or color figure charges

- Immediate publication on acceptance

- Inclusion in PubMed, CAS, Scopus and Google Scholar

- Research which is freely available for redistribution

Submit your manuscript at www.biomedcentral.com/submit 